\title{
The fracture mechanism of softwood via hierarchical modelling analysis
}

\author{
Dong Wang ${ }^{1,2}$, Lanying Lin $2,3^{*} \mathbb{D}$, Feng Fu ${ }^{2}$ and Mizi Fan ${ }^{3}$
}

\begin{abstract}
A hierarchical model of softwood was developed to effectively analyze stress concentration and predict initial fracture of the wood cell wall under different loading scenarios. The results indicated that the simulated stress concentration regions of the tracheid wall approximately matched the experimental initial fracture locations. The stress concentration and initial fracture of the tracheid wall under longitudinal tensile stress occurred in the $\mathrm{S}_{2}$ layer. In the cases of pure longitudinal-radial (LR) or longitudinal-tangential (LT) in-plane shear loading, the highest stresses are observed in the $S_{1} / S_{2}$ interface and the $S_{3}$ layer, but the initial fractures of the tracheids of the neutral layer under the LR or LT shear stress only occurred in the $S_{1} / S_{2}$ interface. Furthermore, the tracheids of the tensile parts outermost of bending specimen were subjected to the longitudinal tension and shear coupling stresses that led to the two kinds of cracks occurring, including trumpet-shaped cracks in the $\mathrm{S}_{2}$ layer, and $\mathrm{S}_{1} / \mathrm{S}_{2}$ interface debonding.
\end{abstract}

Keywords: Softwood, Hierarchical model, Stress concentration, Initial fracture

\section{Introduction}

Wood is an extremely stiff and tough natural composites material in relation to its density. It has long been used as building materials. The excellent material properties of wood are closely related to its hierarchical structure (Fig. 1), i.e., from the honeycomb structure to the chemical polymeric structure [1]. At the molecular level, the cell wall mainly consists of cellulose, lignin, and other organic molecules, such as hemicelluloses. The cell wall, as a mesoscale structure, is a concentric laminated structure that is comprised of four discrete layers in which the orientation of cellulose microfibrils varies, as does the chemical compositions [2]. Moving toward the macroscopic scale, solid wood can be viewed as a honeycomb network of cells cemented together by the middle lamella (ML). Further, the prediction of fractures in wood or wooden components has become increasingly more important for practical application. Many researchers have invested a significant amount of effort in the analysis of the structure and fracture relationships of wood [35 ] and have sought the recipes for the optimal design of

\footnotetext{
${ }^{*}$ Correspondence: linly@caf.ac.cn

${ }^{2}$ Research Institute of Wood Industry, Chinese Academy of Forestry, Beijing 100091, China

Full list of author information is available at the end of the article
}

composite materials and construction in the framework of biomimicking concepts.

Fracture mechanics provides a rational method to quantificationally predict the failure of wood macrostructures when propagating crack is a major contributor to the failure [6]. For wood, the critical stress-intensity factors $\left(K_{\mathrm{IC}}\right.$ and $\left.K_{\text {IIC }}\right)$ are a function of the wood species and are affected by many of the same factors that affect other wood material properties, e.g., grain, specific gravity, and moisture content $[5,7,8]$. However, this method does not take into account the influence of the initial crack on the wood fracture. Furthermore, as has been determined by the in situ scanning electron microscope or light microscope, the initial fracture in wood rays occurred under longitudinal tensile and bending loads [3, $9,10]$. The stick-slip type of crack growth has also been observed, and new crack planes are often formed at the growth ring border $[9,10]$. Although the initial crack and crack propagation in the wood macrostructure have been well understood $[3,9,10]$, very few attempts have been made to investigate the crack initiation and growth modes along with fracture mechanisms at cellular level.

Fractures must proceed through the wood cells, and, therefore, the degree of stress and location of the cell wall play an important role in characterizing 


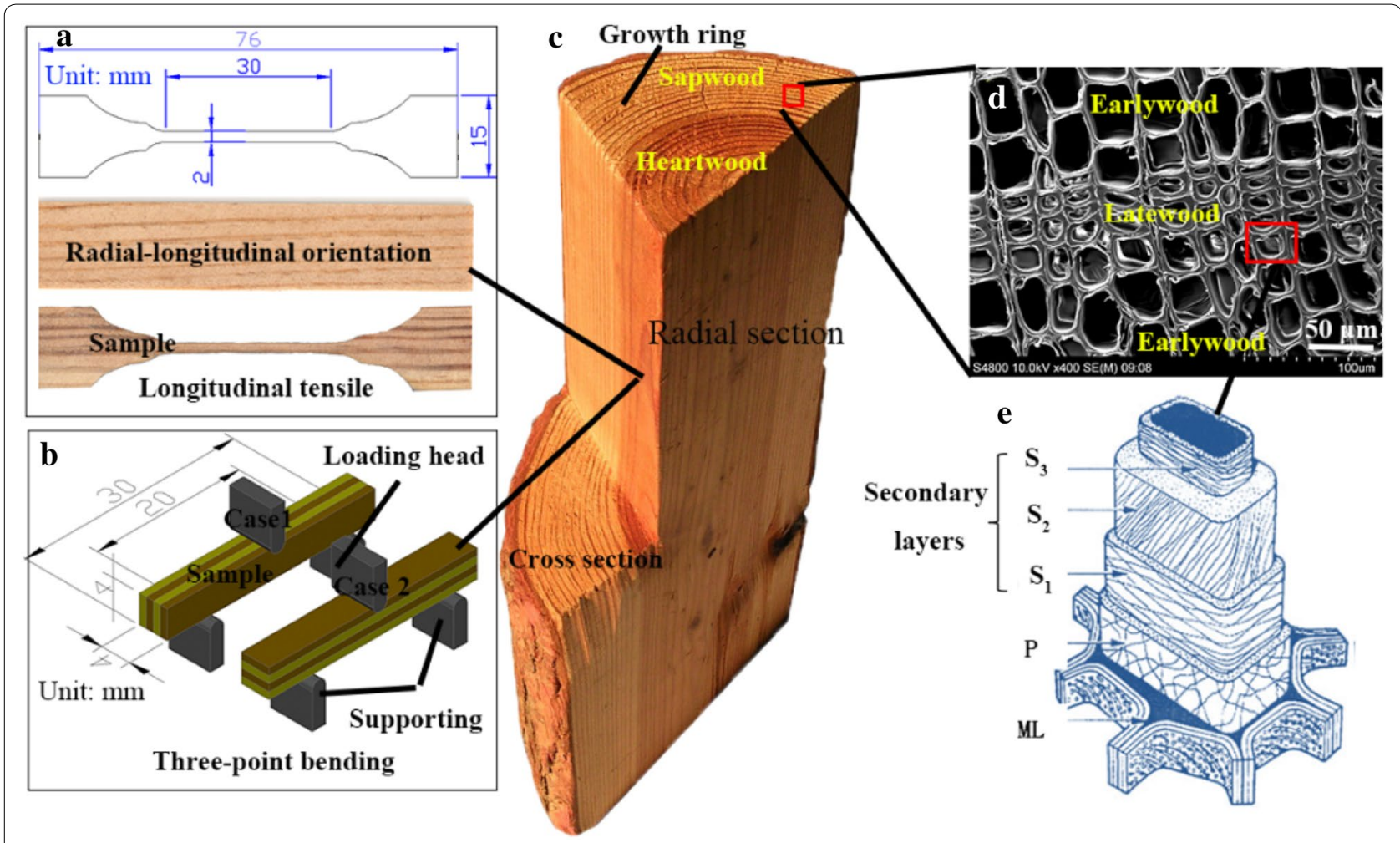

Fig. 1 Preparation of tensile and bending samples and wood multiscale structures. a Longitudinal tensile; b three-point bending; c solid wood; d honeycomb structure; e cell wall concentric laminated structure

the fracturing of wood. Four types of cell fracture are recognized according to the rupture position: intercell, intrawall, transverse, and longitudinal transwall [11-13]. The cell wall fracture, as well as propagation under longitudinal tensile load, was reviewed by Mark [14], and the results indicated that the initiation fracture occurred in the secondary wall $S_{1}$ layer or the $S_{1} /$ $\mathrm{S}_{2}$ interface, rather than in the ML layer. However, the previous research results also showed that, when wood bore longitudinal tensile stress or bend, the initiation cracks of cell walls occurred in the $S_{2}$ layer [15]. Therefore, it is evident that the initial crack and crack propagation in the cell wall is not fully understood.

The finite element analysis (FEA) of the hierarchical model of softwood was developed as an effective model to predict deformation and stress concentration in the cell wall that might become the sites of later damage initiation [16-18]. Qing and Mishnaevsky found that the hierarchical model could predict the distribution of regions of maximum principal stress in the cell wall that corresponds to different loading cases [17]. However, it is still unclear how to correlate the modelled stress concentration regions in the cell wall with the actual initial crack location, which is important for the practical application of the model.
The presented work is to develop a softwood hierarchical model to simulate the stress concentration regions of the cell wall, and the predicted results are verified through experimental results of initial fracture and its propagation. Finally, the influences of the microstructures, including the chemical contents and the microfibril angles (MFAs), on the fractures of the cell walls of softwood were also analyzed.

\section{Materials and methods Materials}

The verification of modelling work was carried out by using softwood materials, which were sampled from the tree trunk of a mature Masson pine (Pinus massoniana Lamb., with annual rings $75 \pm 5$ ) at a height of $1.5 \mathrm{~m}$. Its basic density was $0.51 \mathrm{~g} / \mathrm{cm}^{3}$. A radial-longitudinal (RL) section of eight growth rings from approximately the 30th to the 38th ring was selected as the experimental material, the average width of growth ring was $2.68 \mathrm{~mm}$ and the earlywood (EW) width was $1.59 \mathrm{~mm}$. Specimens of clear small sample for longitudinal tensile testing were designed to be of radial-longitudinal orientation with a dumbbell-type shape, as shown in Fig. 1a, to analyze the initial crack and crack propagation at the scale of the cell wall under longitudinal tensile stress. The 
object of this design was to create a larger gripping area to avoid the possibility of slippage in the tensile testing grip, to prevent stress concentration at the grips, and to force the fracture to occur in the constricted neck area. Furthermore, the straight-line segment of the neck area ensured that the wood grain was parallel to the longitudinal tensile load. As illustrated in Fig. 1a, the thickness of the radial-longitudinal orientation specimen was $1 \mathrm{~mm}$, and the neck of the tension specimens was designed for the EW. Specimens used for an in situ three-point bending test were designed to be of a standard trisection $(4 \times 4 \times 30 \mathrm{~mm}$ (radial $\times$ tangential $\times$ longitudinal), Fig. 1b). All the specimens were conditioned in a vacuum desiccator of $\mathrm{NaCl}$ saturated solution until equilibrium moisture content, which was around $13.4 \%$.

\section{Methods}

\section{Geometric parameters measurement of Masson pine wood} cells

The growth ring boundary of the Masson pine is distinct; the transition from the EW to the latewood (LW) is abrupt (Fig. 1c) [19], and the cell shape is nearly rectangular (Fig. 1d). The tangential sizes of the EW and LW cells are similar, and are therefore equal to the average of their tangential sizes. The geometric parameters of the EW and LW cells (the cell radial and tangential dimensions, and the thickness of each layer of cells) were measured with an atomic force microscope (AFM, in Fig. 2) [20]. Furthermore, according to a previous report [17], the thicknesses of the ML and P layers were 75\% and $25 \%$ that of the compound middle lamella (CML), respectively. All parameters of the cell sizes are listed in Table 1. The filleting treatment in the cell corner was used to smoothly connect the radial and tangential walls. The filleting arc radius of the LW was $4 \mu \mathrm{m}$, and the EW was $8 \mu \mathrm{m}$.

\section{Softwood structure modelling}

To generate a quantitative hierarchical model for the structures represented in Fig. 1d (honeycomb structure) and Fig. 1e (cell wall concentric laminated structure), some simplified assumptions are made for different length scales: (1) At the macroscale, softwood is considered a bundle of rectangular cells of prescribed
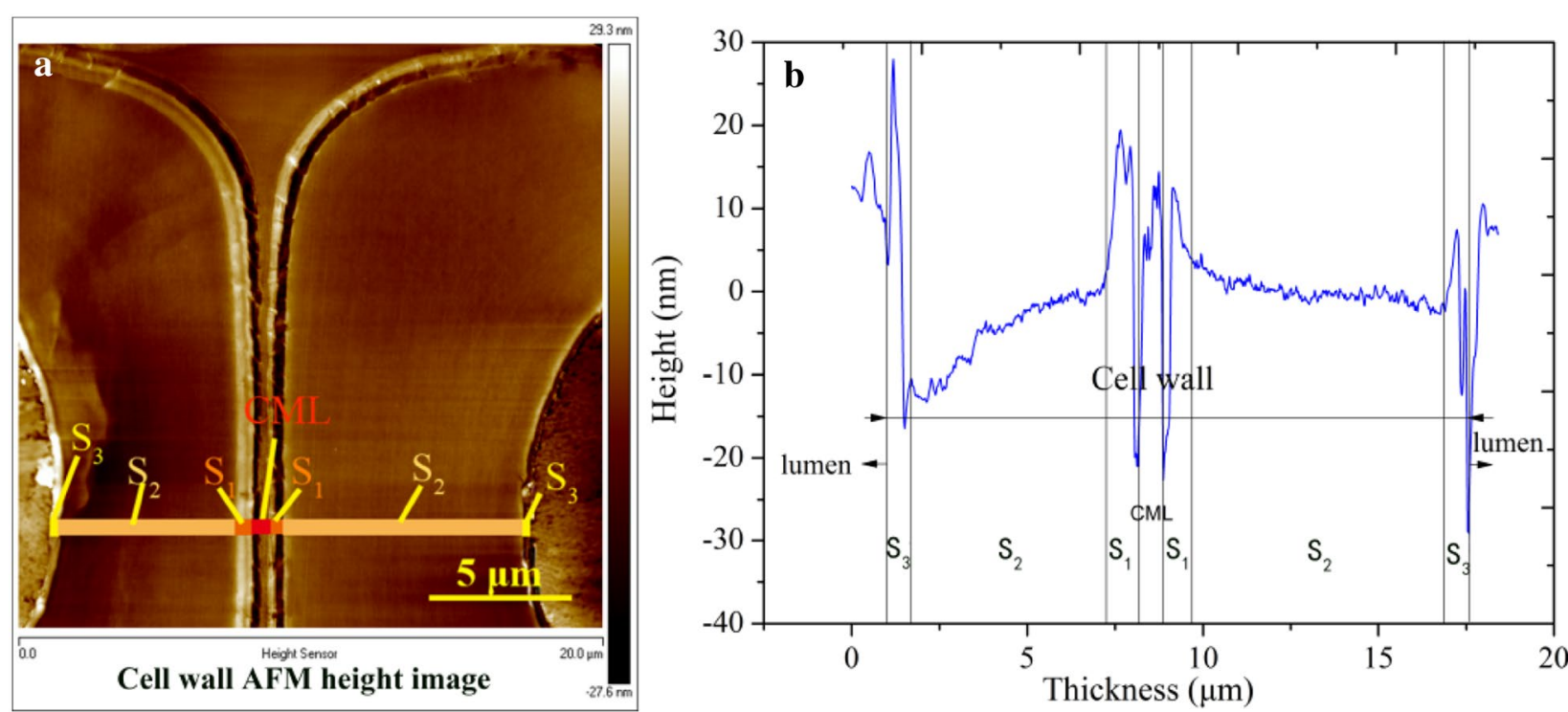

Fig. 2 Geometrical parameters of cell wall measurement via AFM. a Cell wall AFM height image; b height distributions along two adjacent cell wall cross sections

Table 1 Cell sizes and thickness of wall layers $(\mu \mathrm{m})$

\begin{tabular}{|c|c|c|c|c|c|c|c|c|c|c|c|}
\hline Thickness & $T$ & $R$ & $R_{\mathrm{T}}$ & $T_{\mathrm{T}}$ & CML & ML & $P$ & $S_{1}$ & $S_{2 R}$ & $S_{2 T}$ & $S_{3}$ \\
\hline LW & 35.86 & 22.21 & 7.46 & 5.05 & 1.23 & 0.93 & 0.30 & 0.48 & 6.60 & 4.19 & 0.38 \\
\hline EW & 37.32 & 54.91 & 1.40 & 2.09 & 0.32 & 0.22 & 0.10 & 0.19 & 0.31 & 0.99 & 0.20 \\
\hline
\end{tabular}

$R_{\mathrm{T}}$ is the thickness of the cell radial wall, $T_{\mathrm{T}}$ is the thickness of the cell tangential wall, $\mathrm{S}_{2 \mathrm{R}}$ is the radial thickness of the secondary cell wall $\mathrm{S}_{2}$ layer, and $\mathrm{S}_{2 \mathrm{~T}}$ is the tangential thickness of the secondary cell wall $S_{2}$ layer 

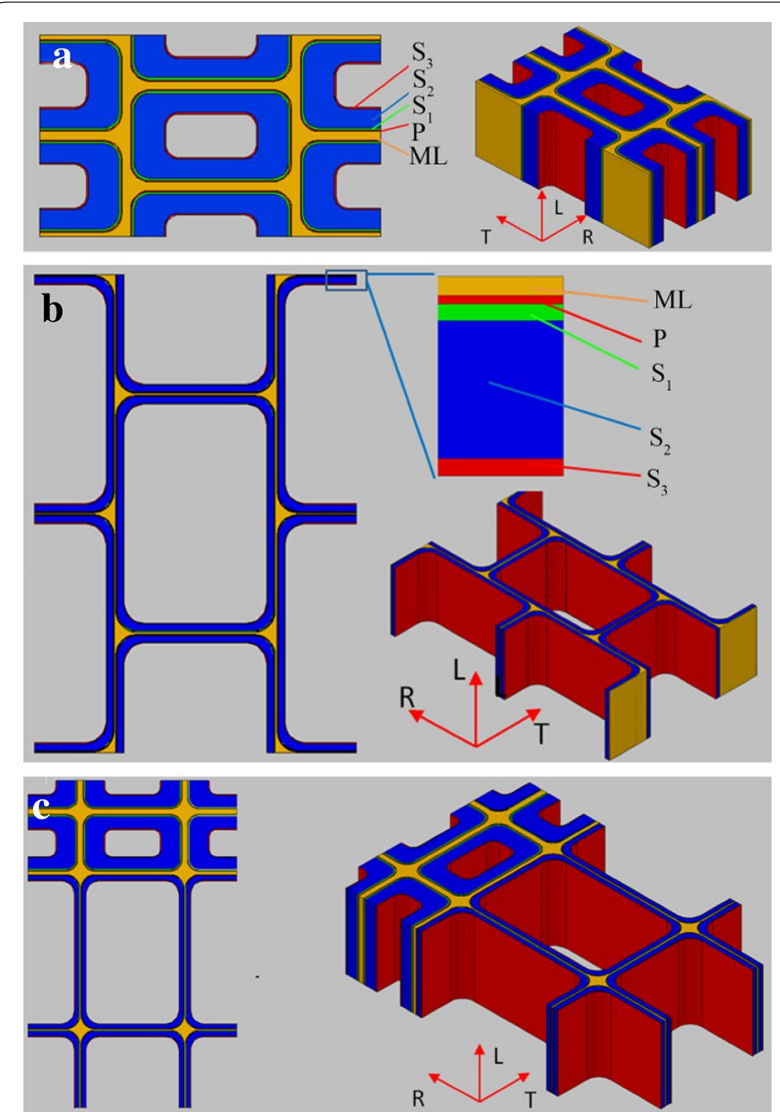

Fig. 3 LW, EW, or EW/LW combination hierarchical models. a LW; b EW; c EW/LW combination cross-sectional tracheids with walls of uniform thickness, (2): at the mesoscale, the cell wall of the tracheid is represented as an elastic laminate with four layers: the primary wall (P), and the secondary walls $S_{1}, S_{2}$, and $S_{3},(3)$ : the ML layer is designated as the bonding layer of two adjacent cell walls, and the interlamination of adjacent two layers was very bonded. The tangential dimension of a cell is the sum of the thickness of two cell radial walls, the lumen tangential size, and half of the ML thickness. The radial dimension of cell is the sum of the thickness of two cell tangential walls, the lumen radial size, and half of the ML thickness. The LW and EW longitudinal sizes are set as $40 \mu \mathrm{m}$. Therefore, three-dimensional hierarchical physical models of the LW (Fig. 3a), EW (Fig. 3b), or the combination of the EW and LW (Fig. 3c) could be established by computer-aided design (CAD).

\section{Finite element analysis (FEA)}

The finite element software ABAQUS 6-14 was used to simulate the stress concentration regions under different loading cases for the above-mentioned softwood hierarchical models. The main processes include mesh, section property, and loading:

Mesh The mesh generation of the softwood hierarchical model was carried out by Hypermesh 2017. The LW model mesh as an example illustrated the mesh generation process, as shown in Fig. 4. The different color regions represented different LW cell wall layers, and the radial-tangential (RT) plane of the LW model was a symmetric structure (Fig. 4a). The meshes of the LW models were produced by the 1/4 RT two-dimensional plane
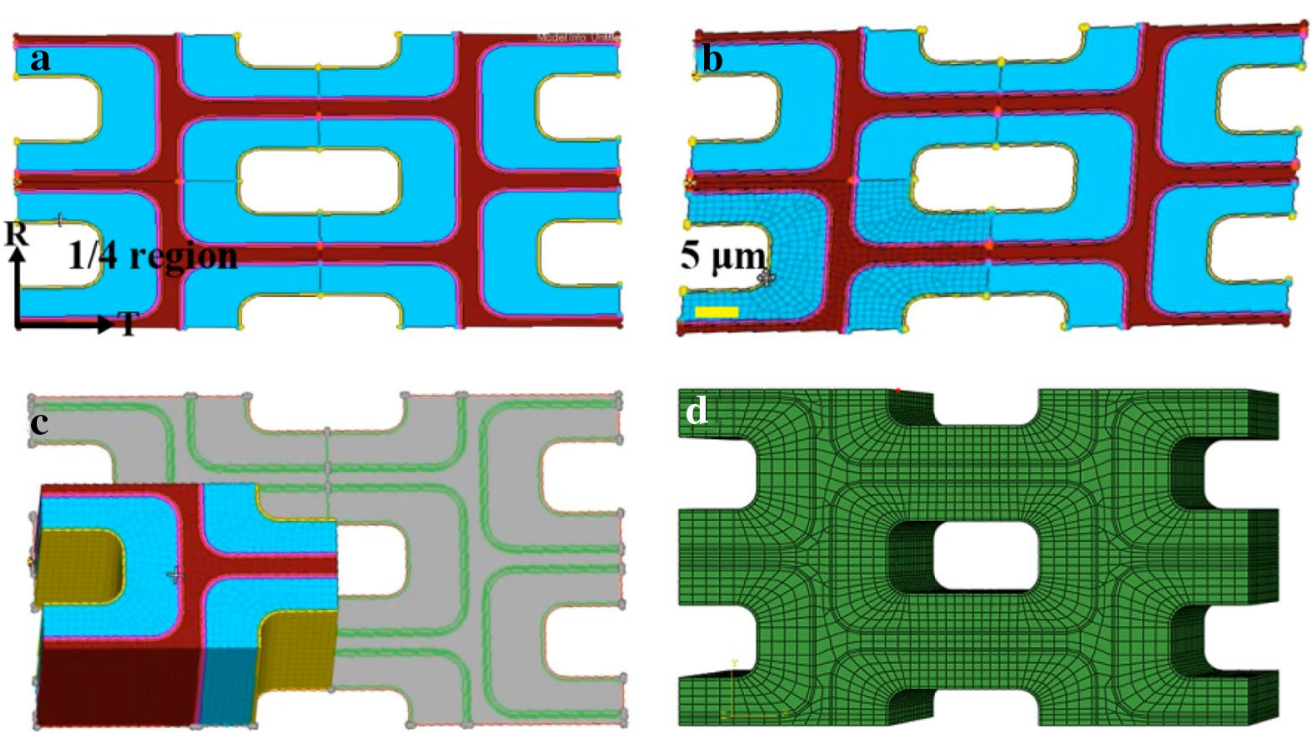

Fig. 4 LW model meshing. a The RT plane of the LW model; b 1/4 RT two-dimensional plane meshing; c 1/4 three-dimensional solid mesh; $\mathbf{d}$ the LW model meshing 
mesh pulling along longitudinal direction and symmetrical treatment. Firstly, the RT plane region was meshed. The element size was $1.000 \mu \mathrm{m}$, and the element shapes were quadrilateral and triangle grids (Fig. 4b). Secondly, the 1/4 RT two-dimensional plane mesh was pulled to $40 \mu \mathrm{m}$ along longitudinal direction, and generated the 1/4 three-dimensional solid mesh (Fig. 4c). Finally, the LW model mesh was produced by the $1 / 4$ three-dimensional solid mesh symmetrical treatment (Fig. 4d).

Section properties At the microscale, the cell wall of each layer represents fibril-reinforced composites that have their own volume fractions and characteristic MFAs. According to previous research [17], the P and ML layers are isotropic materials, and their elastic constants are listed in Table 2. However, the three secondary layers are anisotropic due to the differences in both their contents of chemical components and their MFAs. Their moduli and Poisson's ratios are listed in Table 3 [21].

Boundary conditions setting and loading For the longitudinal tensile loading, the boundary conditions setting mainly are shown in Additional file 1: Fig. S1. (1) Firstly, the three degree of freedoms in radial $(\mathrm{R})$, tangential $(\mathrm{T})$ and longitudinal $(\mathrm{L})$ directions of the TR plane were restricted (Additional file 1: Fig. S1A); Secondary, the two degree of freedoms in $\mathrm{T}$ and $\mathrm{R}$ directions in the ordinate origin were restricted in order to prevent the model to move along the $\mathrm{L}$ direction (Additional file 1: Fig. S1B); thirdly, the degree of freedom in the $\mathrm{R}$ directions of one point of the $\mathrm{T}$ axis was restricted in order to limitation the model rotation around the L-axis (Additional file 1: Fig. S1C). However, the boundary condition of the LR or LT in-plane pure shear loadings was only that the three degree of freedoms in $\mathrm{R}, \mathrm{T}$, and $\mathrm{L}$ directions of the $\mathrm{TR}$ plane were restricted, as shown in Additional file 1: Fig. S2. To study the stress concentration in the elastic range

\section{Table 2 Isotropic elastic constants for $M$ and $P$}

\begin{tabular}{lll}
\hline Layer & $\boldsymbol{E}(\mathrm{GPa})$ & $\boldsymbol{\gamma}$ \\
\hline $\mathrm{M}$ & 2.82 & 0.30 \\
$\mathrm{P}$ & 3.97 & 0.28 \\
\hline
\end{tabular}

$E$ is the elasticity modulus, $\gamma$ is Poisson's ratio of the model, the unit cells were subjected to three different strain loadings: uniaxial tensile loading (Additional file 1: Fig. S1D), and LR and LT in-plane pure shear loadings (Additional file 1: Fig. S2). The stress concentration region in cell wall under uniaxial tensile strain loading could prove cell wall fracture under longitudinal tension load, and the uniaxial tension and in-plane shear analyses were conducted to examine the cell wall fracture in the bending test under the tension and shear complex stress conditions. The following strain values are applied:

$$
\varepsilon_{\mathrm{L}}=0.001 ; \quad \varepsilon_{\mathrm{LR}}=0.001 ; \quad \varepsilon_{\mathrm{LT}}=0.001 .
$$

Longitudinal tensile and in situ three-point bending tests Tensile fracture experiments were carried out by using a micro-mechanical testing machine (Instron 5848 Crop, USA). The maximum load was $2 \mathrm{kN}$, and the loading rate was $0.15 \mathrm{~mm} / \mathrm{min}$. The tensile strength was the average of 15 samples. The in situ three-point bending tests were performed in a SEM chamber (SS-550, Shimadu, Japan), and a miniature mechanical testing device with a maximum load capacity of $1 \mathrm{kN}$ was installed inside the chamber. The dynamic fracture processes of the specimens during bending were examined in real time, and SEM images of the crack propagation path were taken at various stages of loading. The load-displacement curves were recorded simultaneously. A three-point bending fixture was used for the bending test. Pressure head loading was exerted on the middle of the specimens, which were fixed by two supporting rods with a span of $20 \mathrm{~mm}$ (Fig. 1b). This span-depth ratio leads to wood shear failure [22]. The loading rate was $0.15 \mathrm{~mm} / \mathrm{min}$. Two special cases of the annual growth ring orientations are considered, namely the annual rings parallel to the direction of the load (vertical annual rings, case 1), and the annual rings normal to the direction of the load (horizontal annual rings, case 2, Fig. 1b). Each kind loading was tested with 15 samples. The tracheids from the tensile part to the neutral layer of bend fracture specimens were under longitudinal tensile and shear coupled loads. The breakage of the outermost area of tensile portion tracheids resulted from longitudinal tensile stresses, and the cell wall breakage of the neutral layer in the bending specimens was equivalent to the cell wall breakage under shear stress.

Table 3 Anisotropy for secondary wall

\begin{tabular}{|c|c|c|c|c|c|c|c|c|c|}
\hline Layer & $E_{\mathrm{T}}(\mathrm{GPa})$ & $E_{\mathrm{R}}(\mathrm{GPa})$ & $E_{\mathrm{L}}(\mathrm{GPa})$ & $\gamma_{\mathrm{RT}}$ & $\gamma_{\mathrm{LT}}$ & $V_{R T}$ & $G_{\mathrm{RL}}(\mathrm{GPa})$ & $G_{\mathrm{TL}}(\mathrm{GPa})$ & $G_{\mathrm{TR}}(\mathrm{GPa})$ \\
\hline $\mathrm{S}_{3}$ & 8.43 & 7.98 & 50.36 & 0.39 & 0.33 & 0.32 & 2.65 & 3.00 & 2.68 \\
\hline $\mathrm{S}_{2}$ & 9.85 & 9.16 & 63.96 & 0.24 & 0.23 & 0.33 & 3.02 & 3.38 & 2.96 \\
\hline$S_{1}$ & 8.54 & 8.02 & 53.10 & 0.38 & 0.33 & 0.32 & 2.66 & 3.02 & 2.66 \\
\hline
\end{tabular}

$E_{i}$ is the elasticity modulus in the $i$ direction of cell wall layers; $\gamma_{i j}$ is the Poisson's ratio of cell wall layers; $G_{i j}$ is the shearing modulus in the $i j$ in-plane of cell wall layers 


\section{Fracture morphology tests}

The any two samples of each kind load were chose to fracture morphology analysis. The fracture surfaces of the samples were further examined using a field emission scanning electron microscope (SEM, Hitachi S-4800, Japan). The operating accelerating voltage was $10 \mathrm{kV}$. Samples were mounted on aluminum stubs with doublesided tape, and sputter-coated with gold. The fracture types for both the growth ring and the cell wall were characterized. After the SEM tests, the cross-sectional fractures and cell geometrical parameters of the cell wall were examined with an AFM using Veeco (USA). The fine cracks on the cross section of fractured cells were presented. The fracture initiation and crack growth of individual cells were analyzed with the crack results of the AFM. The standard tapping mode probes (BRUKER Model: RTESP-300) were used. The length of the cantilever was $125 \mu \mathrm{m}$, and the resonance frequency was
$300 \mathrm{kHz}$. The breakage parts of the tensile and bending samples were embedded by resin. The cell lumen and the cell wall crack were fully impregnated by the vacuum and pressure processing. This method can distinguish tensile or bending fracture cracks in the cell wall, as well as the cracks caused by subsequent AFM sample preparation.

\section{Results and discussion}

Cell wall stress distribution through the FEA

of the softwood hierarchical model

\section{The longitudinal tensile stress}

Figure 5 illustrates the maximum principal stress distributions corresponding to the above-proposed loading cases. It can be seen in Fig. 5 that the regions of highest stress (which might become sites of later damage initiation) are different under different loading conditions. The highest stress concentrations of the LW or EW models under longitudinal tensile load are

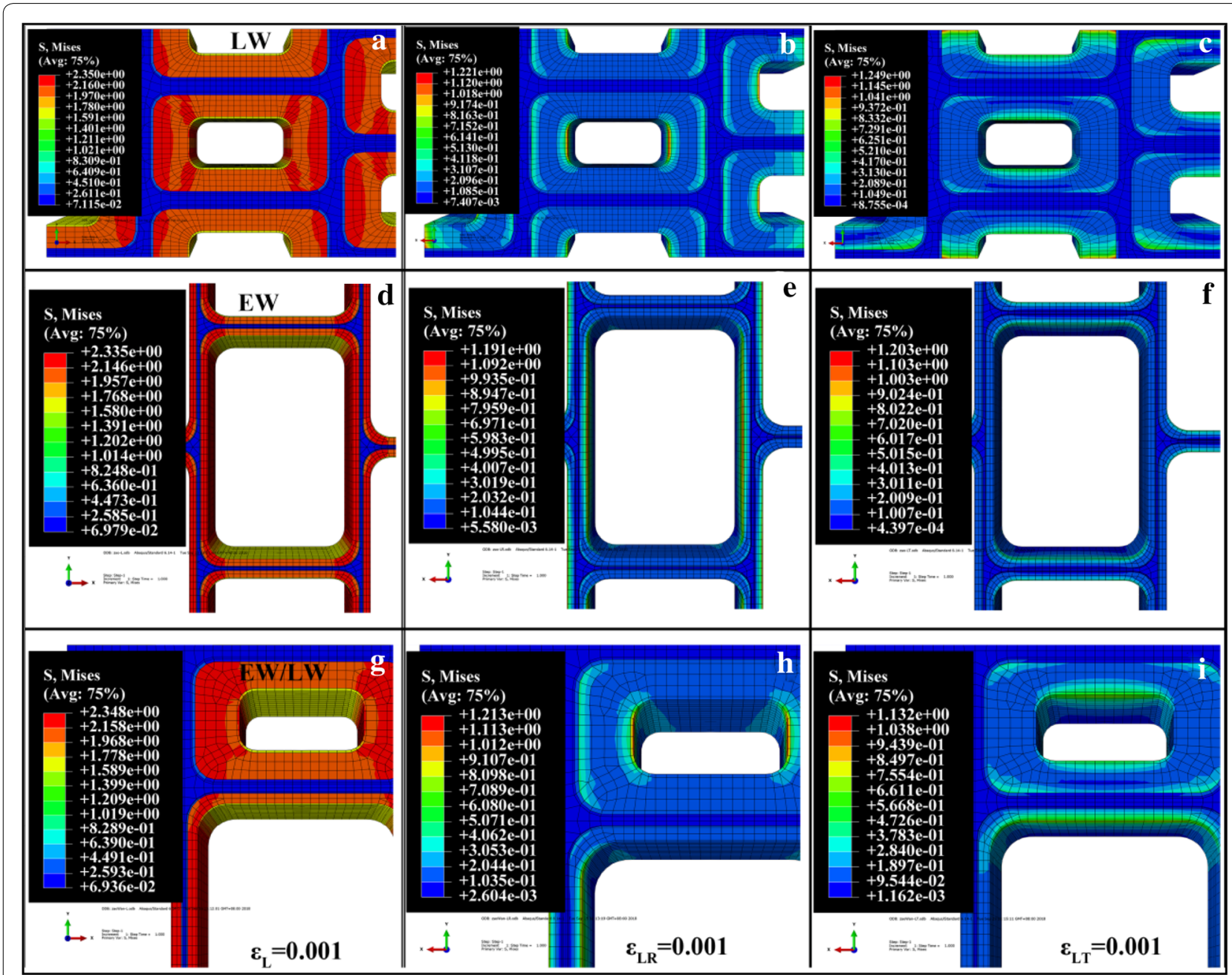

Fig. 5 Maximum principal stress distributions corresponding to loading cases 
observed in the outside of the cell radial wall $\mathrm{S}_{2}$ layer (Fig. 5a, d). The highest stress concentrations of the EW or LW parts of the EW/LW combination model were consistent with those of the EW model or LW model (Fig. 5g). Furthermore, there is an abrupt stress change on the interface between the $S_{1}$ and $S_{2}$ layers that indicate that the interface is a mechanical interface (Fig. 5a, d, g).

\section{The RL and TL in-plane shear stresses}

In the case of LR in-plane pure shear loading, the highest stresses of the LW are observed in the $S_{3}$ layer in the radial cell wall, and the $S_{1} / S_{2}$ layer in the radial cell wall also an interface of stress abrupt change (Fig. 5b). The highest stresses for the EW are observed in the $\mathrm{S}_{1} / \mathrm{S}_{2}$ interface in the radial wall cell corner, and in the $\mathrm{S}_{3}$ layer (Fig. 5e). The stress distributions in the EW or LW parts of the EW/LW combination model were similar to those of the EW model or the LW model, respectively. Furthermore, for the case of TL in-plane shear loading, the stress concentrations of the LW model are observed in $\mathrm{S}_{3}$ layer of the tangential wall and the $S_{1} / S_{2}$ interface in the cell corner (Fig. 5c), and the EW model is observed in $S_{3}$ layer of the tangential wall. The stress concentrations of the EW/LW combination model are observed in the EW tangential wall of the EW/LW border, and the stress concentrations of the LW part of the combination model are $S_{3}$ layer of the tangential wall and the $S_{1} / S_{2}$ interface in the cell corner (Fig. 5i).

\section{Verification via experimental testing: the fracture morphology of tracheid cell wall Longitudinal tensile fracture}

The load-displacement of the EW under longitudinal tension is shown in Additional file 1: Fig. S3A, and the strength was $77.05 \pm 5.29 \mathrm{MPa}$. The EW tracheid breakage of the Masson pine under longitudinal tensile load is transverse transwall, as shown in Additional file 1: Fig. S3B. The detailed breakage cracks of the tracheid cross section were illustrated by the AFM tapping amplitude images in Fig. 6. The experiments show that there are two kinds of cracks in the tracheid cell wall cross section: trumpet-shaped cracks in the $S_{2}$ layer (Fig. 6a), and cracks along the $S_{1} / S_{2}$ interface (Fig. $6 \mathrm{~b}$ ). According to the directions of the trumpet-shaped crack tip, it is speculated that the initial fracture of the tracheid wall fracture process occurred in the $\mathrm{S}_{2}$ layer, and the crack then propagated into the $S_{1} / S_{2}$ interface. Furthermore, the initial fracture positions were associated with the cell wall corner in the locations with an abrupt change in wall thickness. It is apparent that that the FEA results are fully in line with experimental tested results; the highest stress concentration regions of the wood cell wall under longitudinal tensile stress occurred in the $\mathrm{S}_{2}$ layer, and also became the sites of later damage initiation for the cell wall.

The initial fracture cracks may have primarily developed at the $\mathrm{S}_{2}$ layer because of the different structures and mechanical properties of the different layers of the cell wall. Firstly, the highest level of matrix (lignin and hemicellulose) concentration occurred in the ML

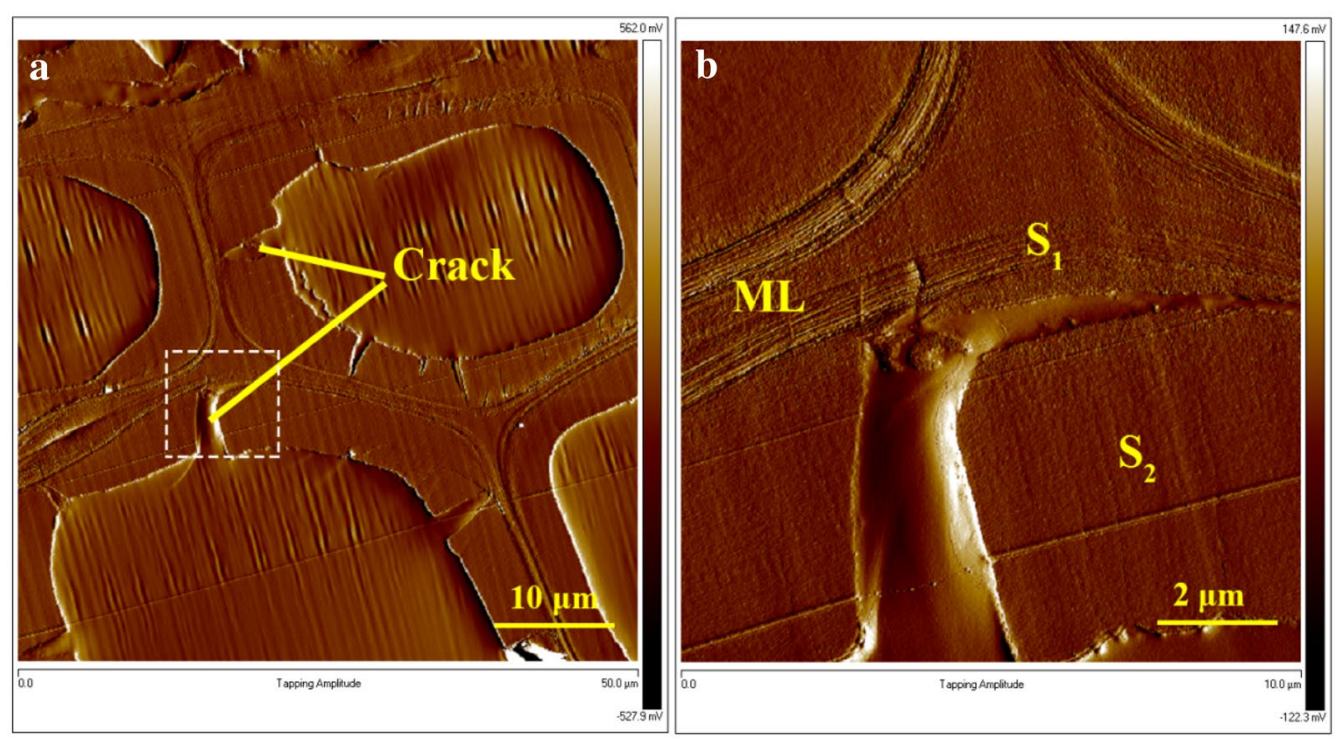

Fig. 6 a Fracture and initial crack location of the cell wall subject to longitudinal tensile stress; $\mathbf{b}$ partial enlarged detail of a 
regions [23-25], and the pectin and protein were in the $P$ layer [26]. This indicated that the CML layer could have an exceptional deformation capability compared to the secondary wall $[27,28]$. As a stress transmitter and weak interface, the CML layer allowed the adjacent secondary wall to incur greater shear slip when the wood was stretched along the longitudinal direction. Hence, cell wall failure under longitudinal tensile load occurred in the secondary cell wall rather than in the CML, and this conclusion has also been widely confirmed in existing research [14]. Secondly, the main difference in the secondary wall three layers is the MFA [29]. The $S_{1}$ and $S_{3}$ fibrils are oriented at large angles to the long axis of the cell, whereas the fibrils of the $S_{2}$ layer are more longitudinally directed. Figure 7 shows the deformation mechanism of the cell wall with different MFAs. The stress component ratio, which was parallel to cellulose chain length direction stress component $\left(\sigma_{F}\right)$ and perpendicular to cellulose chain length direction stress component $\left(\sigma_{M}\right)$, decreased with the MFA $(\theta)$ increasing. The ratio actually represented the cotangent value of MFA. Under the larger of parallel to cellulose chain length direction stress component, the longitudinal tensile deformations of the $\mathrm{S}_{2}$ layer mainly included the deformation of shear slip between the matrix and microfibril $[28,30]$ and the deformations of cellulose extension [31,32]. The shear slip deformation led to adaptive orientation of cellulose (Fig. 7). However, for the $S_{1}$ or $S_{3}$ layers of larger MFA, the larger of perpendicular to cellulose chain length direction stress component led to the shear slip deformation between microfibril and matrix increasing compared with the $S_{2}$ layer [33]. So the large deformation of $S_{1}$ or $S_{3}$ layer also led to stress redistribution and concentration occurring in the $\mathrm{S}_{2}$ layer.

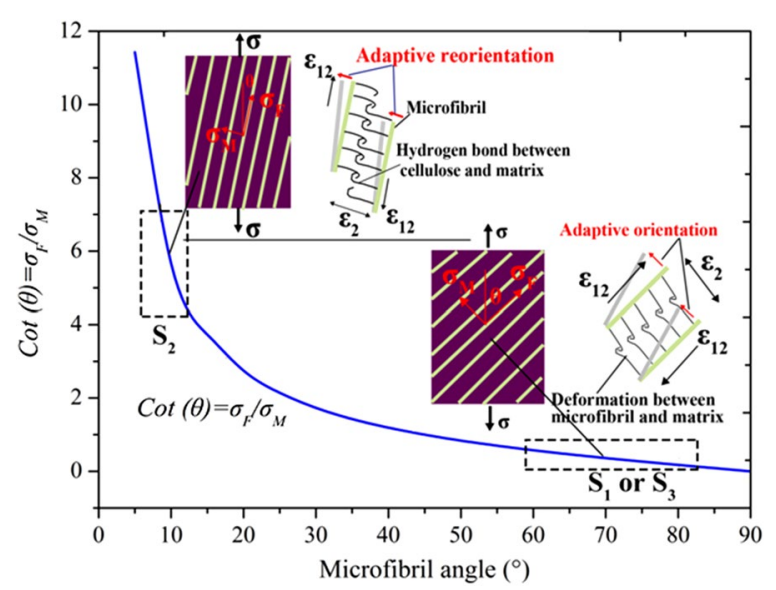

Fig. 7 Deformation mechanism of the cell wall with different MFAs

\section{Three-point bending fracture}

The load-displacement curves of two kinds bend loading are shown in Additional file 1: Fig. S3A, the bending strengths are $82.23 \pm 4.12 \mathrm{MPa}$ and $56.50 \pm 3.27 \mathrm{MPa}$, respectively. For the case in which the loading direction was parallel to the growth rings, the neutral layer was located perpendicular to the growth ring plane (Additional file 1: Fig. S3C). The LW tracheids of the tensile parts outermost were subjected to longitudinal tension and LR shear coupling stresses, but the LW tracheids of the neutral layer bore only the LR shear stress [22]. The fracture morphologies of the LW tracheids cross section for the outermost tensile parts and the neutral layer are provided in Fig. 8. There are two kinds of cracks in the cell wall cross section of the outermost tensile parts: trumpet-shaped cracks in the $S_{2}$ layer, and $S_{1} / S_{2}$ interface debonding (Fig. 8a). The former crack was caused by longitudinal tensile stress, and the latter was due to the LR in-plane shear stress. It is apparent that FEA modelling was able to map the radial cracks in the $S_{2}$ layer as approved by above-mentioned longitudinal tensile tests. The LR shear stress in the neutral layer was the greatest and led to cell wall fracturing in the $S_{1} / S_{2}$ interface (Fig. 8b). This is consistent with the results of the LW model under pure RL shear stress.

When wood growth rings were perpendicular to the direction of the load and the EW part was approximately located in the neutral layer (Additional file 1: Fig. S3D), greater shear slip occurred in the neutral layer. This result is also consistent with the hierarchical model result, which found that the stress concentrations of the EW/LW combination model were observed in the EW tangential wall of the growth ring border (Fig. 5i). The LW tracheid wall breakage of the tensile part outmost of a specimen is shown at the scale of individual cells in Fig. 8c. The greatest tensile stress in the tensile part outmost led to the $S_{2}$ layer fracture, and the LT in-plane shear stress caused $S_{1} /$ $\mathrm{S}_{2}$ interface debonding in the cell corner. The modelling results are in line with these experimental outcomes. The EW tracheid wall breakage near the neutral layer under LT in-plane shear stress occurred in the $S_{1} / S_{2}$ interface, especially in the cell corner. However, this result was not consistent with the EW model results under LT in-plane shear stress.

The tracheid failure mechanism under radial or tangential loading bend is illustrated in Fig. 9. When the wood was bent, the tracheids of the tensile part underwent a combination of tensile and shear loads. According to the longitudinal tension experiment and FEA results, the initial fracture and stress concentration of the tracheid wall under the longitudinal tension occurred at the $\mathrm{S}_{2}$ layer. Furthermore, the MFA difference between the $S_{1}$ or $S_{3}$ and the $S_{2}$ layer caused stress concentration at the $S_{1} / S_{2}$ 

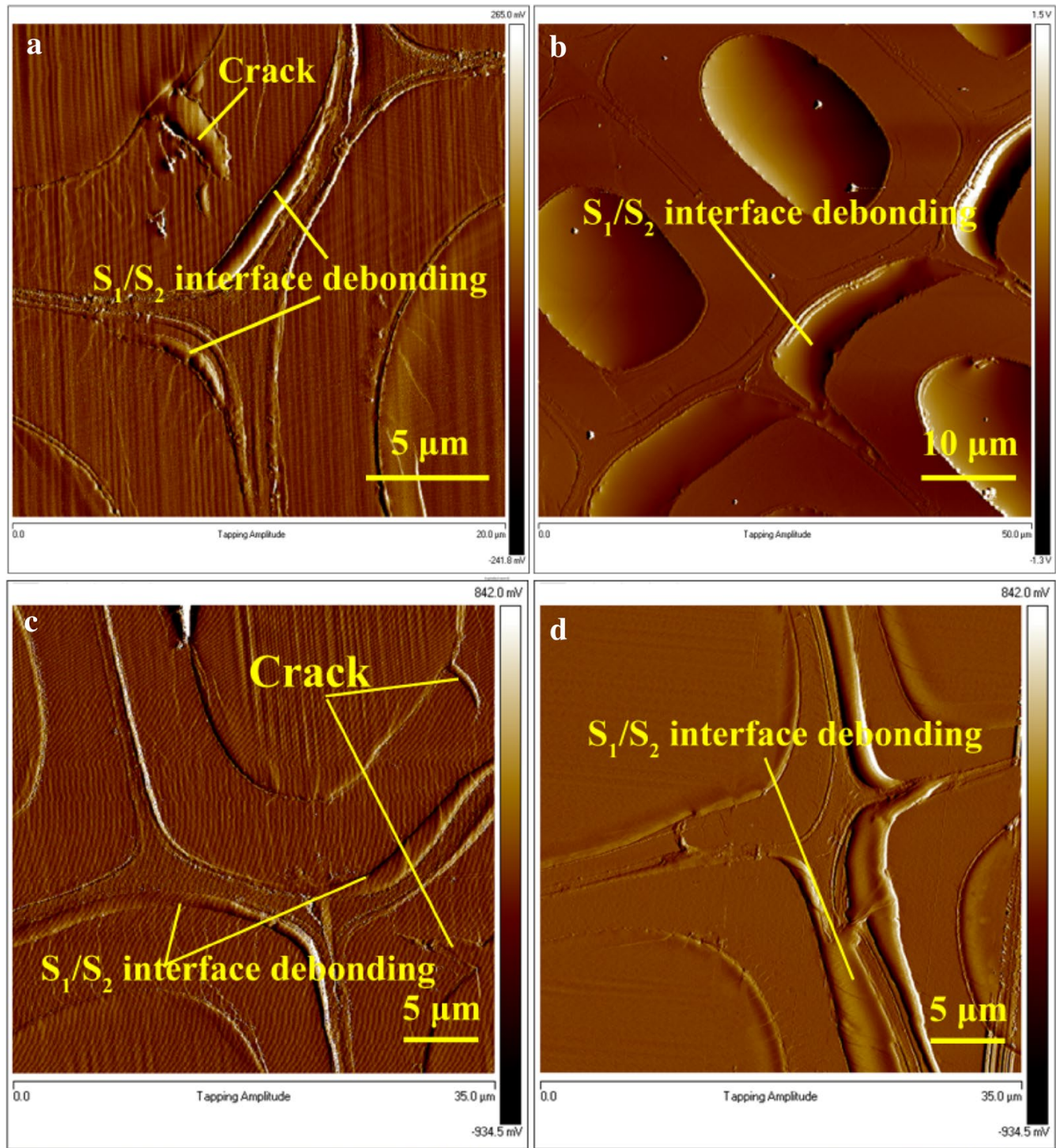

Fig. 8 Fractures of the tracheids under bend loading. a The LW fracture of the tensile parts outermost under tangential loading bend; $\mathbf{b}$ the LW fracture of the neutral layer under tangential loading bend; $\mathbf{c}$ the LW fracture of the tensile parts outermost under radial loading bend; $\mathbf{d}$ the EW fracture of the neutral layer under radial loading bend

interface under the shear stress. The shear stress resulted in the debonding of the $S_{1} / S_{2}$ interface. For the bending specimens, the tensile stress decreased gradually from the outside of the tensile part to the neutral layer, but the shear stress increased. This could explain why the cracks of the intrawall breakage types of tracheids near the neutral layer occurred in the $S_{1} / S_{2}$ interface.

\section{Conclusions}

A 3D hierarchical computational model of the stress on softwood is developed. The theoretical stress concentration results of hierarchical models were verified with the experimentally tested results. The stress concentration and initial fracture of the tracheid under longitudinal tensile stress occurred in the $\mathrm{S}_{2}$ layer. In the case of pure LR or LT in-plane shear loading, the stress concentration and fracture region of the tracheid of the neutral layer are observed in the $S_{1} / S_{2}$ interface by the FEA and experiment. Furthermore, the tracheids of the tensile parts outermost were subjected to the longitudinal tension and shear coupling stresses that led to the two kinds of cracks occurring, including trumpet-shaped cracks in the $S_{2}$ layer, and $S_{1} S_{2}$ interface debonding. 


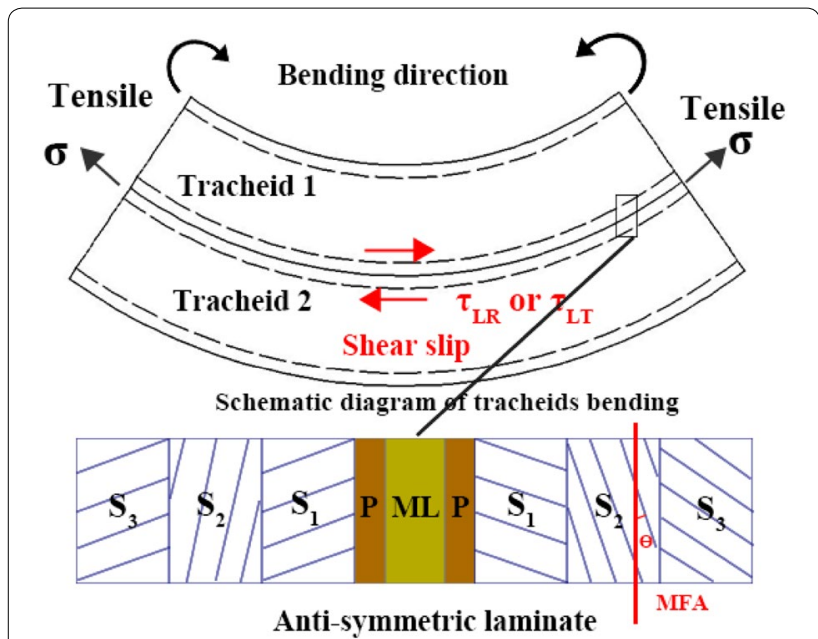

Fig. 9 Stress analysis of the cell wall under radial or tangential loading bend

\section{Supplementary information}

Supplementary information accompanies this paper at https://doi. org/10.1186/s10086-019-1837-x.

Additional file 1: Fig. S1. Boundary conditions of the longitudinal tension. ( $A$ : The three degree of freedoms of $R, T$, and $L$ directions were restricted of the TR plane; $B$ : Degree of freedoms of $T$ and $R$ directions in the ordinate origin ( $O$ point) were restricted; $C$ : Degree of freedom of $R$ directions of one point $\left(\mathrm{O}_{1}\right.$ point) of the T axis was restricted; $\mathrm{D}$ : Load condition). Fig. S2. The three degree of freedoms of $R$, $T$ and $L$ directions were restricted of the TR plane for the $L T$ and $L R$ shear, respectively. ( $A$ : The load direction was the R direction; $\mathrm{B}$ : The load direction was the T direction).

Fig. S3. A: The load-displace curves of the longitudinal tension and threepoint bend;B: SEM images showing the longitudinal tensile fracture; $C$ : SEM images showing the tangential bend loading fracture; D: SEM images showing the radial bend loading fracture.

\section{Abbreviations}

LR: longitudinal-radial; LT: longitudinal-tangential; RL: radial-longitudinal; RT: radial-tangential; EW: earlywood; LW: latewood; $M L$ : middle lamella; P: primary wall; CML: compound middle lamella; MFAs: microfibrillar angles; FEA: finite element analysis; CAD: computer aided design; AFM: atomic force microscope; $\mathrm{R}$ : radial direction; $\mathrm{T}$ : tangential direction; L: Iongitudinal direction.

\section{Acknowledgements}

Not applicable.

\section{Authors' contributions}

DW in collaboration with LL formulated and designed the experiments. DW performed the experiments and analyzed the data. DW, LL, and MF wrote the paper. FF guided and edited the overall structure of this review article. All authors read and approved the final manuscript.

\section{Funding}

This work was supported by the National Natural Science Foundation of China [Grant Number 31770597, 2017] and the program from the China Scholarship Council [201803270009, 2018]

\section{Availability of data and materials}

The authors confirm that the data supporting the findings of this study are available within the article.

\section{Competing interests}

The authors declare that they have no competing interests.

\section{Author details}

${ }^{1}$ Nanjing Forestry University of Materials and Science and Engineering, Nanjing 210037, China. ${ }^{2}$ Research Institute of Wood Industry, Chinese Academy of Forestry, Beijing 100091, China. ${ }^{3}$ College of Engineering, Design and Physical Sciences, Brunel University, Middlesex UB8 3PH, UK.

Received: 24 June 2019 Accepted: 16 October 2019

Published online: 28 October 2019

\section{References}

1. Salmén L, Burgert I (2009) Cell wall features with regard to mechanical performance. A review COST Action E35 2004-2008: wood machiningmicromechanics and fracture. Holzforschung 63:121-129. https://doi. org/10.1515/HF.2009.011

2. Hofstetter K, Gamstedt EK (2009) Hierarchical modelling of microstructural effects on mechanical properties of wood. A review COST Action E35 2004-2008: wood machining-micromechanics and fracture. Holzforschung 63:130-138. https://doi.org/10.1515/HF.2009.018

3. Frühmann K, Burgert I, Stanzl-Tschegg SE (2003) Detection of the fracture path under tensile loads through in situ tests in an ESEM chamber. Holzforschung 57:326-332. https://doi.org/10.1515/HF.2003.048

4. Conrad MP, Smith GD, Fernlund G (2007) Fracture of solid wood: a review of structure and properties at different length scales. Wood Fiber Sci 35:570-584

5. Stanzl-Tschegg SE, Navi P (2009) Fracture behaviour of wood and its composites. A review COST Action E35 2004-2008: wood machiningmicromechanics and fracture. Holzforschung 63:139-149. https://doi. org/10.1515/HF.2009.012

6. Patton-Mallory M, Cramer SM (1987) Fracture mechanics: a tool for predicting wood component strength. For Prod J 37:39-47

7. Jeronimidis $G$ (1980) The fracture behaviour of wood and the relations between toughness and morphology. Proc R Soc Lond 208:447-460. https://doi.org/10.1098/rspb.1980.0062

8. Reiterer A, Sinn G, Stanzl-Tschegg SE (2002) Fracture characteristics of different wood species under mode I loading perpendicular to the grain. Mat Sci Eng A-Struct 332:29-36. https://doi.org/10.1016/s0921 -5093(01)01721-X

9. Bodner J, Schlag MG, Grüll G (1997) Fracture initiation and progress in wood specimens stressed in tension. Part I. Clear wood specimens stressed parallel to the grain. Holzforschung 51:479-484. https://doi. org/10.1515/hfsg.1997.51.5.479

10. Sippola M, Frühmann K (2002) In situ longitudinal tensile tests of pine wood in an environmental scanning electron microscope. Holzforschung 56:669-675. https://doi.org/10.1515/HF.2002.101

11. Koran Z (1968) Electron microscopy of tangential tracheid surfaces of black spruce produced by tensile failure at various temperatures. Svensk Papperstidning 71:567-576

12. Cote WA, Hanna RB (1983) Ultrasound characteristics of wood fracture surfaces. Wood Fiber Sci 15:135-163. https://doi.org/10.1007/BF00129437

13. Zink AG, Pellicane PJ, Shuler CE (1994) Ultrastructural analysis of softwood fracture surfaces. Wood Sci Technol 28:329-338. https://doi.org/10.1007/ BF00195280

14. Mark RE (1967) Cell wall mechanics of tracheids. Tests of mechanical properties. Yale University Press, New Haven and London, pp 27-53

15. Fahlén J, Salmén L (2002) On the lamellar structure of the tracheid cell wall. Plant Biology 4:339-345. https://doi.org/10.1055/s-2002-32341

16. Mishnaevsky L Jr, Qing H (2008) Micromechanical modelling of mechanical behaviour and strength of wood: state-of-the-art review. Comp Mater Sci 44:363-370. https://doi.org/10.1016/j.commatsci.2008.03.043

17. Qing H, Mishnaevsky L Jr (2009) 3D hierarchical computational model of wood as a cellular material with fibril reinforced, heterogeneous multiple layers. Mech Mater 41:1034-1049. https://doi.org/10.1016/j.mechm at.2009.04.011

18. Mishnaevsky L Jr, Qing H (2010) 3D multiscale micromechanical model of wood: from annual rings to microfibrils. Int J Solids Struct 47:1253-1267. https://doi.org/10.1016/j.ijsolstr.2010.01.014 
19. Richter HG, Grosser D, Heinz I, Gasson PE (2004) IAWA list of microscopic features for softwood identification. IAWA J 25:1-70. https://doi. org/10.1163/22941932-90001616

20. Hanley SJ, Gray DG (1994) Atomic force microscope images of black spruce wood sections and pulp fibres. Holzforschung 48:29-34. https:// doi.org/10.1515/hfsg.1994.48.1.29

21. Astley RJ, Stol KA, Harrington JJ (1998) Modelling the elastic properties of softwood. Eur J Wood Wood Prod 56:43-50. https://doi.org/10.1007/ s001070050262

22. Babiak M, Gaff M, Sikora A, Hysek Š (2018) Modulus of elasticity in three-and four-point bending of wood. Compos Struct. https://doi. org/10.1016/j.compstruct.2018.07.113

23. Schmidt M, Schwartzberg AM, Perera PN (2009) Label-free in situ imaging of lignification in the cell wall of low lignin transgenic Populus trichocarpa. Planta 230:589-597. https://doi.org/10.1007/s0042 5-009-0963-x

24. Ji Z, Ma J, Xu F (2014) Multi-scale visualization of dynamic changes in poplar cell walls during alkali pretreatment. Microsc Microanal 20:566576. https://doi.org/10.1017/s1431927614000063

25. Wang X, Keplinger T, Gierlinger N, Burgert I (2014) Plant material features responsible for bamboo's excellent mechanical performance: a comparison of tensile properties of bamboo and spruce at the tissue, fibre and cell wall levels. Ann Bot-London 114:1627-1635. https://doi.org/10.1093/ aob/mcu180

26. Stevanic JS, Salmén L (2008) Characterizing wood polymers in the primary cell wall of Norway spruce (Picea abies (L.) Karst.) using dynamic FT-IR spectroscopy. Cellulose 15:285-295. https://doi.org/10.1007/s1057 0-007-9169-1
27. Keckes J, Burgert I, Frühmann K, Müller M, Kölln K, Hamilton M, Burghammer M, Roth SV, Stanzl-Tschegg S, Fratzl P (2003) Cell-wall recovery after irreversible deformation of wood. Nat Mater 2:810-813. https://doi. org/10.1038/nmat1019

28. Weinkamer R, Fratzl P (2011) Mechanical adaptation of biological materials - the examples of bone and wood. Mat Sci Eng C-Mater 31:11641173. https://doi.org/10.1016/j.msec.2010.12.002

29. Funada R, Abe H (2005) Review — the orientation of cellulose microfibrils in the cell walls of tracheids in conifers. IAWA J 26:161-174. https://doi. org/10.1163/22941932-90000108

30. Barthelat F, Yin Z, Buehler MJ (2016) Structure and mechanics of interfaces in biological materials. Nat Rev Mater 1:16007. https://doi. org/10.1038/natrevmats.2016.7

31. Salmén L, Bergström E (2009) Cellulose structural arrangement in relation to spectral changes in tensile loading FTIR. Cellulose 16:975-982. https:// doi.org/10.1007/s10570-009-9331-z

32. Šturcová A, Eichhorn SJ, Jarvis MC (2006) Vibrational spectroscopy of biopolymers under mechanical stress: processing cellulose spectra using bandshift difference integrals. Biomacromol 7:2688-2691. https://doi. org/10.1021/bm060457m

33. Burgert I (2006) Exploring the micromechanical design of plant cell walls. Am J Bot 93:1391-1401. https://doi.org/10.3732/ajb.93.10.1391

\section{Publisher's Note}

Springer Nature remains neutral with regard to jurisdictional claims in published maps and institutional affiliations.

\section{Submit your manuscript to a SpringerOpen ${ }^{\odot}$ journal and benefit from:}

- Convenient online submission

- Rigorous peer review

- Open access: articles freely available online

- High visibility within the field

- Retaining the copyright to your article

Submit your next manuscript at $\boldsymbol{\nabla}$ springeropen.com 